\title{
PENGARUH KESIAPAN BELAJAR TERHADAP PRESTASI BELAJAR MAHASISWA PENDIDIKAN FISIKA UNIVERSITAS MUSLIM MAROS
}

\author{
Reski Idamayanti \\ Pendidikan Fisika Universitas Muslim Maros \\ reski.fisika@gmail.com
}

\begin{abstract}
The effect of learning readiness on the learning achievement of students of physics education, Muslim University of Maros. The purpose of this research was to determine the effect of learning readiness on the learning achievement of Physics Education Students the Muslim University of Maros. There are two variables in this study, namely the independent variable (X) Learning Readiness and the dependent variable (Y) Learning achievement.. Data collection in this study was carried out using product-moment correlation and ttest. This analysis is used to test the hypothesis about the presence or absence of influence between the two variables. The sample of this study used a random sample. The hypotheses in this study are Ho: There is no effect of student learning readiness on learning achievement and Ha: there is an effect of student learning readiness on learning achievement with a significance level of $5 \%$ or with a confidence level of $95 \%$ with a descriptive correlational method. Based on learning readiness an average of $75.62 \%$. Then on the test $H a$ is accepted and $H 0$ is rejected, which means that there is a significant influence between learning readiness and achievement.
\end{abstract}

Keywords: creative thinking, thinking skills, reflection strategies

Abstrak: Pengaruh kesiapan belajar terhadap prestasi belajar mahasiswa pendidikan fisika Universitas Muslim Maros. Tujuan penelitian ini adalah untuk mengetahui pengaruh kesiapan (readiness) Belajar terhadap Prestasi belajar Mahasiswa Pendidikan Fisika Universitas Muslim Maros. Variabel dalam penelitian ini ada dua yaitu variabel bebas (X) Kesiapan Belajar dan Variabel terikat (Y) Prestasi belajar. Pengumpulan data dalam penelitian ini dilakukan dengan menggunakan korelasi product-moment dan uji-t. Analisis ini digunakan untuk menguji hipotesis mengenai ada tidaknya pengaruh antara kedua variabel. Sample penelitian ini menggunakan sample acak. Hipotesis dalam penelitian ini adalah Ho: Tidak Ada Pengaruh Kesiapan Belajar Mahasiswa Terhadap Prestasi belajar dan Ha: Ada Pengaruh Kesiapan Belajar Mahasiswa terhadap Prestasi belajar dengan taraf signifikansi 5\% atau dengan taraf kepercayaan $95 \%$ dengan metode deskriptif korelasional. Berdasarkan kesiapan belajar rata-rata sebesar $84,36 \%$ sedangkan analisis prestasi belajar (Mid) mahasiswa rata-rata 74,25. Dalam pengujian tersebut $\mathrm{Ha}$ diterima dan $\mathrm{HO}$ ditolak yang berati diantara kesiapan belajar ada pengaruh secara signifikan terhadap prestasi belajar.

Kata kunci: kesiapan belajar, prestasi belajar 
Belajar adalah cara seseorang untuk mengetahui suatu perihal yang belum bisa dilakukan. Seseorang baru dapat belajar tentang sesuatu apabila dalam dirinya sudah terdapat "Readiness" (kesiapan) untuk mempelajari sesuatu itu. Pada kenyataannya setiap individu mempunyai perbedaan individu, maka masingmasing individu mempunyai latar belakang perkembangan yang berbeda-beda. Hal ini menyebabkan adanya pola pembentukan readiness yang berbeda-beda pula di dalam diri masing-masing individu. Begitu pula readiness dalam belajar sangatlah berpengaruh pada perkembangan pribadi seseorang untuk mematangkan kesediaannya dalam belajar tersebut dengan begitu seseorang akan mudah dan siap menerima sesuatu yang akan dipelajari dalam pembelajarannya itu sendiri. Proses belajar merupakan aktivitas psikis berkenaan dengan bahan belajar. Aktivitas belajar yang dilakukan oleh mahasiswa merupakan sebagai suatu proses, dalam mempelajari sesuatu, karena belajar merupakan kegiatan pokok, selain itu juga belajar merupakan kunci dalam pembentukan kompetensi peserta didik, karena peserta didik baru bisa belajar apabila semua yang berkaitan dengan proses belajar sudah ada kesiapan dari dalam dirinya.

Di era globalisasi ini mahasiswa dituntut harus lebih aktif dan mandiri dalam proses belajar, tidak pasif dan hanya mengharapkan/mengandalkan dosen dan orang lain sebagai pemberi materi. Misal dosen tidak bisa hadir di dalam kelas untuk mengajar maka, mahasiswa harus berinisiatif mencari bahan/sumber belajar sendiri dengan cara memanfaatkan perpustakaan sekolah, dengan mencari buku pelajaran yang sesuai dan belajar mandiri untuk memahami materi/pelajaran yang belum atau yang sudah diberikan oleh dosennya. Dengan kesiapan belajar yang dimilikinya maka mahasiswa mampu menjadi generasi penerus bangsa ini serta mampu bersaing hidup secara mandiri, mampu menghadapi tantangan kehidupan dan memiliki kualitas serta karakter yang baik.. Menurut Slameto (2010:113) "Kesiapan belajar adalah keseluruhan kondisi seseorang yang membuatnya siap untuk memberi respon atau jawaban di dalam cara tertentu terhadap suatu situasi”. Sedangkan menurut Cronbach (2006: 191) "Kesiapan belajar adalah segenap sifat atau kekuatan yang membuat seseorang dapat bereaksi dengan cara tertentu". Dari pendapat-pendapat itu bisa disimpulkan bahwa, kesiapan belajar merupakan suatu kesatuan usaha untuk melengkapi kemampuan yang dimilikinya dalam mengambil tindakan/memberi respon dari apa yang akan/sedang dihadapinya dalam belajar

Faktor yang membentuk kesiapan meliputi: 1) Perlengkapan dan pertumbuhan fisiologi; ini menyangkut pertumbuhan terhadap kelengkapan pribadi seperti tubuh pada umumnya, alat-alat indera, dan kapasitas intelektual; 2) Motivasi, yang menyangkut kebutuhan, minat serta tujuan-tujuan individu untuk mempertahankan serta mengembangkan diri (Soemanto, 2006: 191).

Adapun prinsip-prinsip kesiapan: 1) Semua aspek perkembangan berinteraksi (saling pengaruh mempengaruhi); 2) Kematangan jasmani dan rohani adalah perlu untuk memperoleh manfaat dari pengalaman; 3) Pengalaman-pengalaman mempunyai pengaruh yang positif terhadap kesiapan; 4) Kesiapan dasar untuk kegiatan tertentu terbentuk dalam periode tertentu selama masa pembentukan dalam masa perkembangan (Soemanto, 2006: 191). Belajar merupakan keharusan yang dilakukan oleh setiap orang yang berpengaruh terhadap tingkah laku, cara berpikir dan pandangan seseorang dalam menyelesaikan suatu masalah. Dengan belajar diharapkan pengetahuan seseorang akan bertambah sehingga mampu menghadapi segala macam tantangan kehidupan. Menurut Slameto (2010: 2), "belajar ialah suatu proses usaha yang dilakukan oleh seseorang untuk memperoleh suatu perubahan tingkah laku yang baru secara keseluruhan, sebagai hasil pengalamannya sendiri dalam interaksi dengan lingkungannya", Menurut Hamdani (2010: 71), "belajar adalah seperangkat proses kognitif yang mengubah sifat stimulasi lingkungan, melalui pengolahan informasi, menjadi kapabilitas baru", sedangkan menurut Syaiful Bahri Djamarah dan Aswan Zain (2006: 10), "belajar adalah proses perubahan perilaku berkat pengalaman dan latihan". 


\section{METODE}

Penelitian ini menggunakan rancangan penelitian deskriptif. Data yang digunakan dalam penelitian adalah data kuantitatif yang didukung oleh data kualitatif. Data kuantitatif didapat melalui angket sebagai instrumen utama penelitian. Sedangkan data kualitatif sebagai pendukung penelitian didapat melalui observasi untuk mendapatkan keterangan tambahan dari subjek penelitian. Populasi dan sampel dalam penelitian ini adalah mahasiswa pendidikan fisika Universitas Muslim Maros.

Dalam penelitian ini, instrumen yang digunakan dua, yaitu angket dan lembar observasi. Untuk mengetahui kesiapan belajar Mahasiswa, maka peneliti melakukan penelitian ini melalui teknik pengumpulan data dengan lembar angket yang jawabannya diperoleh langsung dari mahasiswa.

Data yang diambil dalam penelitian ini adalah data kuantitatif dan data kualitatif. Data kuantitatif adalah hasil jawaban dari mahasiswa terhadap instrument angket sedangkan data kualitatif berasal dari lembar observasi. Angket yang telah diisi oleh mahasiswa kemudian dianalisis dengan cara menghitung jumlah skor jumlah poin pernyataan. Setelah itu, dianalisis secara deskriptif sehingga akan diketahui hasilnya melalui teknik penskoran tersebut yakni seberapa besar kesiapan mahasiswa dalam mengikuti proses pembelajaran.

\section{HASIL DAN PEMBAHASAN}

Instrumen yang digunakan dalam penelitian ini adalah instrumen angket tertutup dan lembar observasi mahasiswa. Menurut Sugiyono (2011: 113) untuk menguji kelayakan penggunaan instrumen dapat digunakan pendapat para ahli tentang aspek-aspek yang akan diukur dengan berlandaskan teori tertentu. Para ahli diminta pendapatnya tentang instrumen yang telah disusun. Hasil validasi menunjukkan bahasa yang digunakan cukup baik, susunan kalimatnya banyak yang harus diperbaiki serta dalam pencapaian variabel penelitian terdapat beberapa item yang harus dihilangkan untuk kemudian ditambahkan item baru yang lebih sesuai. Berdasarkan penelitian tentang kesiapan belajar mahasiswa dalam mengikuti proses belajar dapat diketahui bahwa tingkat kesiapan belajar mahasiswa.(tabel 1)

Tabel 1. Hasil angket kesiapan belajar mahasiswa dalam mengikuti proses pembelajaran

\begin{tabular}{|c|c|c|c|}
\hline No & Indikator & Kesiapan belajar (\%) & Kriteria penafsiran \\
\hline 1 & Kondisi fisik & 79,92 & baik \\
\hline 2 & Kondisi mental (emosi) & 82,00 & Sangat baik \\
\hline 3 & Kebutuhan-kebutuhan (materi) & 90,67 & Sangat baik \\
\hline 4 & Keterampilan & 84,85 & Sangat baik \\
\hline & $\begin{array}{c}\text { Jumlah } \\
\text { Rata-rata persentase }\end{array}$ & $\begin{array}{c}337,44 \\
84,36\end{array}$ & Sangat baik \\
\hline
\end{tabular}

jawaban mahasiswa kemudian dimasukkan ke dalam rumus lalu didapatkan hasil berupa persentase. Dari persentase inilah dapat dilihat tingkat kesiapan mahasiswa dalam belajar. Menurut Riduwan (2011: 15)

Data yang diperoleh pada lembar observasi dilihat rata-rata hasilnya pada subjek penelitian dengan cara menjumlahkan semua skor yang diperoleh kemudian dibagi dengan
Rata-rata Persentase 84,36 Sangat Baik Berdasarkan Tabel hasil angket kesiapan belajar mahasiswa dalam mengikuti proses pembelajaran diperoleh hasil rata-rata persentasenya yaitu $84,36 \%$ termasuk dalam kategori sangat baik. Hal ini menunjukkan bahwa rata-rata mahasiswa memiliki kesiapan. meliputi faktor jasmaniah, faktor psikologis dan faktor kelelahan. 
Karst : Jurnal Pendidikan Fisika dan Terapannya Volume 3 | Nomor 2 | 74

p-ISSN: 2622-9641 e-ISSN: 2655-1276

\section{PEMBAHASAN}

Dari hasil penelitian diperoleh rata-rata Persentase 84,36 Sangat Baik. Hal ini menunjukkan bahwa rata-rata mahasiswa memiliki kesiapan dalam pembelajaran. Faktor yang sebagian besar mempengaruhi kesiapan belajar dan dijadikan indikator penelitian oleh penulis adalah faktor eksternal yakni faktor keluarga, faktor sekolah dan faktor masyarakat serta faktor internal yang

Hasil penelitian ini diperkuat teori dikemukakan oleh Slameto (2010:59) yang mengemukakan bahwa kesiapan perlu diperhatikan dalam 67 proses belajar karena saat siswa sudah memiliki persiapan belajar maka hasil belajarnya akan lebih baik. Kesiapan diperlukan dalam proses belajar mengajar karena dalam kondisi siap siswa akan cenderung lebih mudah untuk mengikuti pembelajaran. Hasil penelitan ini juga memperkuat hasil penelitian yang dilakukan oleh Ika Nur Atmawati (2013) dengan judul "Pengaruh Motivasi, Kesiapan Belajar dan Lingkungan Keluarga terhadap Hasil Belajar Akuntansi Siswa Kelas XI Akuntansi SMK Teuku Umar Semarang Tahun Ajaran 2012/2013". Hasil penelitian ini menunjukkan bahwa terdapat pengaruh positif dan signifikan Kesiapan Belajar terhadap Hasil Belajar Akuntansi Siswa Kelas XI SMK Teuku Umar Semarang Tahun Ajaran 2012/2013 yang ditunjukkan dengan nilai thitung $=2,347$ dengan

\section{DAFTAR PUSTAKA}

Amri, S., \& Ahmadi, L. K. 2010. Konstruksi Pengembangan Pembelajaran Pengaruhnya Terhadap Mekanisme dan Praktik Kurikulum. Jakarta: Prestasi Pustakaraya.

Arikunto, S. 2010. Dasar-dasar Evaluasi Pendidikan. Yogyakarta: Bumi Aksara

Arikunto, S. 2010. Prosedur Penelitian suatu Pendekatan Praktik. Jakarta: Rineka Cipta.

Atmawati, I. 2013. Pengaruh Motivasi, Kesiapan Belajar dan Lingkungan Keluarga Terhadap Hasil Belajar Akuntansi Siswa koefisien determinasi sebesar 0,1505 yang artinya sebesar $15,05 \%$ variabel ini mempengaruhi Hasil Belajar Akuntansi Siswa.

\section{PENUTUP}

Berdasarkan hasil analisis data dan pembahasan maka dapat diambil kesimpulan bahwa rata-rata mahasiswa mempunyai kesiapan belajar yang baik dapat dilihat dari nilai kesiapan rata-rata sebesar $84,36 \%$. Hal ini menunjukan bahwa kesiapan belajar mahasiswa. Dan ratarata hasil belajar mahasiswa diperoleh sebesar 74,25 yang mempunyai kategori baik dan hasil analisis angket dan hasil belajar dengan menggunakan uji-t dapat disimpulkan bahwa ada pengaruh yang signifikan antara kesiapan mahasiswa terhadap hasil belajar mahasiswa.

Berdasarkan kesimpulan di atas ada beberapa saran dari penulis. Pertama, bagi mahasiswa, diharapkan disaat proses belajar mengajar agar lebih memperhatikan Readiness (kesiapan) belajarnya. Kedua, bagi dosen, diharapkan agar dapat memperhatikan Readiness (kesiapan) belajar mahasiswa pada proses belajar mengajar berlangsung. Dan ketiga, bagi kampus, diharapkan dapat menyediakan fasilitas yang memadai guna guna menunjang Readiness (kesiapan) belajar mahasiswa dalam kegiatan belajar mengajar.

Kelas XI Akuntansi SMK Teuku Umar Semarang Tahun Ajaran 2012/2013. Skripsi. Pendidikan Ekonomi UNNES.

Darso. 2011. Kesiapan Belajar Mahasiswa dan Interaksi Belajar Mengajar Terhadap Prestasi Belajar. Invotec, 7(2), 139-151.

Djamarah, S. B., \& Zain, A. 2010. Strategi Belajar Mengajar. Jakarta: Rineka Cipta.

Hadis, A. 2008. Psikologi dalam Pendidikan. Bandung: Alfabeta. 
Karst : Jurnal Pendidikan Fisika dan Terapannya Volume 3 | Nomor $2 \mid 75$

p-ISSN: 2622-9641 e-ISSN: 2655-1276

Madjid, A. 2009. Perencanaan Pembelajaran. Bandung : PT Remaja Rosda Karya.

Mulyani, D. 2013. Hubungan kesiapan belajar mahasiswa dengan prestasi belajar. Konselor, 2(1), 27-30.

Nasution, S. 2011. Metode Research (Penelitian Ilmiah). Jakarta: BumiAksara.
Slameto. 2010. Belajar dan Faktor-Faktor yang Mempengaruhinya. Jakarta: Rineka Cipta

Sugiyono. 2011. Metode Penelitian Kuantitatif Kualitatif dan $R \& D$. Bandung: Alfabeta. 